\title{
ČEZMEJNO SODELOVANJE MED KOROŠKO IN SLOVENIJO NA PODEŽELSKEM PROSTORU
}

Igor Roblek*

\section{Izvleček}

Avstrija je od leta 1995 članica Evropske unije (EU). S pristopom k EU se je spremenila tudi regionalna politika in regionalni razvoj. Vlada je močno podpirala ustanovitev regij, ki so kot glavno nalogo imele in imajo implementacijo projektov, ki služijo boljšemu razvoju določenega območja. V Avstriji je bil v 80ih letih 20. stoletja uveden sistem decentraliziranega planiranja in decentralnega razvoja posebno podeželja in perifernih območij.

Danes avstrijske regije, med njimi tudi CARNICA Rož, razvijajo in uresničujejo razne projekte, npr. v kmetijstvu, gozdarstvu in turizmu. Posebno pomembno je čezmejno sodelovanje in razvijanje skupnih programov $s$ tega področja.

Ključne besede: Regija, regionalni razvoj, turizem, kmetijstvo in gozdarstvo, čezmejno sodelovanje.

\section{CROSSBODRDER CO-OPREATINO BETWEEN CARANTHIAN AND SOVENIAN RURAL AREAS}

\section{Abstract}

Since 1995 Austria has been a member of the European Union (EU). By the accession to the EU the regional policy and the regional development were changed. The Government strongly supported the establishment of regions, which have had a duty to implement the projects that serve to a

\footnotetext{
*Dr., CARNICA Region Rosental/Rož, Verlach/Borovlje, Avstrija.
} 
certain region better development. In the 80 s they introduced in Austria a decentralised planning and development system, especially of the rural and peripheral regions.

Today, the Austrian regions, and among them also CARNICA Rosental, develop and realise various projects, e.g. in agriculture, forestry and tourism, whereby the cross-border co-operation and common programmes development in this field are of particular importance.

Key words: Region, regional development, tourism, agriculture and for restry, crossborder co-operation.

\section{Spremembe na podeželju}

Podeželski prostor se je v teku 20. stoletja izredno močno spremenil. Že v začetku stoletja je bil (tako kot vso zgodovino poprej) prostor, ki ga je človek v glavnem koristil samo za kmetijstvo in gozdarstvo (predvsem za lastno preživetje). V prostorih, kjer je bila železova ruda ali katerokoli drugo naravno bogastvo (npr. zlato ali druge kovine) so se ta bogastva pojavljala in izkoriščala. Z industrijsko revolucijo, ki je na Koroško in tudi v Slovenijo prišla relativno pozno, se je veliko spremenilo. Podeželsko prebivalstvo se je bilo zaradi vse manjših možnosti za preživetje prisiljeno izseliti v mesta in urbana središča, kjer so nastajali veliki industrijski obrati v začetku industrijske dobe, ki so v začetku delali še zelo neefektivno in so zato potrebovali ogromno delovne sile. Podjetniški pionirji (kot npr. Henry Ford in drugi) so $v$ industrijski delovni proces vnesli popolnoma nove pristope in postopke ter tako omogočili inovacije, ki so dotedanji delovni/produkcijski krog revolucionalizirali in produktivnost industrijskih obratov močno povišali. Skupna točka vseh inovacij je bil dvig produktivnosti in s tem v zvezi tudi znižanje produkcijskih stroškov. V procesu industrializacije, še posebno po 2. svetovni vojni, je večina industrijskih podjetij zavoljo znižanja produkcijskih stroškov zmanjšala delovno silo ob sočasnemu dvigu produktivnosti. V luči gospodarske rasti so po drugi svetovni vojni v Zahodni Evropi izhajali iz polarizacijske teorije, po kateri naj bi gospodarstvo samo (odnosno gospodarska rast) poskrbelo, da bodo v vseh regijah približno enaki gospodarski in življenjski pogoji. Teorija je predpostavljala, da gospodarska rast sama privede do zmanjšanja razlik (disparitet) v vseh regijah. 
Teoretična pričakovanja se $v$ praksi niso izpolnila, kar je postalo vse bolj opazno v začetku 70-ih let, ko je v Evropi zavladala prva večja gospodarska kriza. Po tej krizi so skorajda vse evropske države začele posebej podpirati podeželske prostore, ki jih pogosto tudi lahko imenujemo periferna območja. Ustanovili so posebne programe, s katerimi so skušali pomagati predvsem razvoju kmetijstva in gozdarstva v celotni regiji. Pričeli so uveljavljati prve podpore za kmetijstvo in gozdarstvo: podpirale so predvsem periferna območja z otežkočenimi produkcijskimi pogoji.

V današnji krizi v kmetijstvu imajo območja, ki so doslej kmetovala in pridelovala kvaliteto bolj kot kvantiteto in se niso podredila vplivu industrijskega kmetovanja, največje možnosti.

V 90-ih letih 20. stoletja, v postindustrijski dobi, se je tudi vloga podeželja radikalno spremenila. Nove komunikacijske tehnologije so prišle tudi $v$ najbolj periferna območja. V današnjem času je potrebno izpostaviti, da ima podeželje prihodnost samo tedaj, če bodo tamkajšnji prebivalci znali izrabiti svoj obstoječi "know how" oz. bodo uspeli čimbolje vključiti človeške vire $v$ regiji.

\section{Avstrijska politika za pomoč/ podporo podeželju}

V Avstriji se je v začetku 70-ih let 20. stoletja ustanovila ÖROK - Öesterreichische Raumordnungskonferenz - Avstrijska konferenca za urejanje prostora. Naloga te konference je, da pomaga in pripravlja za zvezno vlado in dežele prostorski plan, razvojne načrte ipd. Politika je opazila, da samo gospodarstvo ne zmore izravnati razlike znotraj države: življenjski in gospodarski pogoji znotraj cele države so približno enaki. Razlika med gospodarsko močnimi in "tranzicijskimi državami" ter "perifernimi območji" znotraj držav članic EU so se iz leta v leto povečale in se še večajo. Klasična razvojna politika pomeni, da veliko podjetje $v$ periferni regiji postavi ali bolje rečeno ustanovi hčerinsko podjetje, ki pa je povsem odvisno in soodvisno od centrale, se je $v$ zadnjih letih tudi izkazala kot napačna, ker ni pripomogla $\mathrm{k}$ boljšemu znotrajregijskemu razvoju, ampak je privedla le do večje odvisnosti. Pri najmanjših gospodarskih krizah se je pogosto izkazalo, da so centrale najprej zaprle podjetja, ki so bila na periferiji. Odpuščanje delovnih mest zlasti na perifernih območjih je privedlo do tega, da so ljudje postali še bolj odvisni od central. Hitro se je pokazalo, da je potrebno to enostransko odvisnost čimprej odpraviti. 
Tako so oblikovali programe za pomoč kmetijstvu oz. še posebej gorskemu kmetijstvu v alpskih krajih. Uredili so tudi podpore za gospodarsko šibka območja, kjer so t.i. regijski menedžerji skušali vnesti in spodbuditi nove projekte.

\section{Strategija endogenega regionalnega razvoja}

Sredi 80-ih let 20. stoletja se je potem močno razširila strategija endogenega regionalnega razvoja, ki temelji predvsem na boljšem izkoriščanju, uporabi in razvoju človeških virov. Začele so se ustanavljati skupine ljudi (regijskih menedžerjev), ki so bile financirane s sredstvi urada zveznega kanclerja (BKA) in poslane $v$ periferna območja, da bi spodbujale in organizirale individualne projekte in programe za endogeni in trajnostni regionalni razvoj. Koncept endogenega in trajnostnega regionalnega razvoja tako temelji tudi na motiviranju lokalnega prebivalstva, da se čim hitreje vključi v razvoj svojega domačega okolja/ prostora.

\section{Podeželski prostor in EU}

Ustvarjanje enakih življenjskih pogojev in enakih življenjskih možnosti na celotnem teritoriju Evropske unije (EU) je eden izmed njenih strateških ciljev, za kar se investirajo tudi precejšnja denarna sredstva. EU je ustanovila strukturne sklade, s katerimi financira hitrejši gospodarski razvoj določenega območja. Pri tem lahko izpostavimo dejstvo, da je za razvoj potrebno čim bolje vključiti lokalno prebivalstvo in programe zastaviti tako, da so v skladu s ciljem notranje socialne in gospodarske kohezije na celotnem območju EU. Cilj je torej izenačenje gospodarskih moči in pogojev vseh držav članic in vseh regij.

Podeželski prostori v EU so zelo raznoliki, kljub temu pa imajo nekatere skupne probleme. Če upoštevamo podpore, ki jih za razvoj podeželja daje Evropska unija državam članicam in tudi državam kandidatkam (ki imajo podpisan pridružitveni sporazum, preko raznih programov - npr. Program PHARE, PHARE CBC, SAPARD in ISPA), so to razmeroma visoka finančna sredstva. Precej sredstev izplačujejo za podporo kmetijstvu in gozdarstvu ter za strukturne sklade in kohezijski sklad, skupno več kot $65 \%$ celotnega proračuna Evropske unije. Po zadnjih škandalih v kmetijstvu (BSE, bolezen norih krav, parkljevka in slinovka) bo potrebno premisliti usmeritev celotne 
kmetijske politike EU in jo preusmeriti. Mislim, da se bo morala kmetijska politika EU dokončno posloviti od subvencioniranja industrijskega kmetijstva in svojo kmetijsko politiko preusmeriti $v$ podporo (zdravih) majhnih kmečkih struktur, ki proizvajajo nasonaraven način in odgovorno do naslednjih generacij. Na ta način bi dali prednost kvaliteti pred kvantiteto, kar nudi obstoječim kmetijam veliko možnosti za preživetje.

Ohranitev dinamičnih podeželskih prostorov, novo partnerstvo med podeželjem in mesti so tudi cilji ESDP - Evropske prostorsko razvojne perspektive. Ta dokument (sprejet leta 1999 v Potsdamu) predlaga smernice za razvoj prostora, za prostorsko planiranje in urejanje $v$ sedanjih članicah EU ter tudi v državah kandidatkah.

Razdeljen je na dva dela2:

(A) doseči uravnotežen in trajnosten razvoj celotnega ozemlja Evropske skupnosti : prispevek k prostorski razvojni politiki ;

(B) ozemlje EU: trendi, možnosti in izzivi.

$\checkmark$ prvem delu tega dokumenta so predstavljene vse glavne politike EU za razvoj prostora in za razvoj prostorskega planiranja. Predstavljene so tudi glavne razlike in glavne pobude za zmanjšanje razlik v razvitosti - uvedba močnejše in učinkovitejše regionalne politike s strani EU. Celotni koncept se ukvarja s trikotnikom: družba - gospodarstvo - okolje.

$\mathrm{V}$ proračunu EU je 32,38 \% sredstev namenjenih strukturni politiki in ribištvu, skoraj polovica celotnega proračuna pa se investira v kmetijstvo. Področji raziskav in tehnološkega razvoja, ki sta za razvoj celotnega ozemlja EU izrednega pomena, pa prejemajo samo 3,8 \% celotnega evropskega proračuna.

Najpomembnejši cilji za prihodnji razvoj EU so ${ }^{3}$ :

- policentričen in uravnotežen prostorski razvoj v EU;

- dinamična, privlačna in konkurenčna mesta in urbanizirane regije;

- avtohton razvoj, raznolika in produktivna kmetijska območja;

- odnosi med mestnimi in kmetijskimi območji.

Posebna pozornost je posvečena predvsem avtohtonemu razvoju podeželskih prostorov, ki naj ostanejo življenjski in gospodarski prostori za razmeroma veliko število ljudi tudi $v$ prihodnje. äe posebno $v$ Avstriji in $v$ Sloveniji je zaradi izredno bogatega kulturnega in naravnega izročila

2 EUROPÄISCHE KOMMISSION; Das EUREK - Europäisches Raumentwicklungskonzept.

3 EUROPÄISCHE KOMMISSION; Das EUREK - Europäisches Raumentwicklungskonzept, stran 20. 
potrebno, da le ti ostanejo tudi funkcionalni. Pri celotni razpravi o razvojnih perspektivah je potrebno upoštevati tudi dejstvo, da je razvoj dober in perspektiven samo tedaj, če se nanj gleda celovito.

\section{Širitev EU}

Posebno poglavje ESDP-ja je namenjeno vprašanju širitve EU na države Vzhodne in Jugovzhodne Evrope, ki je gotovo eden izmed največjih projektov EU. Prostor in število prebivalcev se bosta s širitvijo EU precej povečalo. Pri sedanji širitvi se bodo včlanile predvsem države, ki so nerazvite in imajo precejšnje gospodarske težave. Znotraj držav kandidatk so precejšnje razlike. Predvideva se, da se bodo po širitvi države EU lahko razdelile na tri stopnje (po razvitosti držav članic):

1. najbolje razite države (države z najvišjim standardom, npr. Avstrija,

Nemčija, Finska, Francija itd.);

2. srednje razvite države (npr. Španija, Slovenija, Portugalska, Grčija itd.);

3. slabše razvite države (npr. Poljska itd.).

Istočasno bo na vsak način potrebna tudi nova orientacija na področju agrarne in strukturne (regionalne) politike in uveljavitev (deloma spremenjenih in novih) kriterijev.

Drugi del ESDP se osredotoča na ozemlje EU in pri tem na trende, možnosti in izzive prostorskega razvoja 4 . Predstavljene so splošne geografske značilnosti in primerjava ozemlja EU z ostalim svetom. Pomembne so tudi razne druge določitve celotnega ozemlja, ki jih je potrebno upoštevati.

\section{Strukturni skladi in koordinacija strukturnih skladov ter novo programsko obdobje}

Strukturni skladi in kohezijski sklad pri celotni regionalni politiki EU igrajo razmeroma pomembno vlogo. Predvsem pri zmanjšanju regionalnih razlik oz. disparitet ${ }^{5}$, ki so med državami članicami EU zelo velike. Da bi zmanjšali te disparitete je EU vzpostavila posebno podporno shemo in programe, ki so finacirani s strani EU. Vloga teh strukturnih skladov, še posebno kohezijskega sklada, ki je namenjen predvsem gospodarsko in finančno zapos-

\footnotetext{
4 EUROPÄISCHE KOMMISSION; Das EUREK - Europäisches Raumentwicklungskonzept, stran 53.
} 
tavljenim regijam, je v pomoči pri njihovemu gospodarskemu in tudi socialnemu razvoju. Po širitvi EU na vzhodne in jugovzhodne države se bo ta vloga strukturnega sklada še povečala. $V$ zadnjih letih so bili in so vidni tudi že rezultati, ki se kažejo v zmanjševanju prej omenjenih disparitet. Cilj teh politik naj bo tudi $v$ prihodnje ravno njihovo zmanjšanje ${ }^{6}$.

Strukturni skladi in kohezijski sklad temeljijo na dveh horizontalnih temeljih. Ta dva temelja sta:

1. trajnostni razvoj in

2. enake možnosti in enak dostop do informacij za vse.

Poleg tega je $v$ okviru reforme teh politik (torej $v$ okviru razprave o AGENDI 2000) prišlo tudi do močnejše vključitve še posebno naravovarstvenega in okoljskega vidika.

Pri razvoju in upravljanju programov je potrebno še posebej upoštevati tudi koncept partnerstva, torej partnersko sodelovanje pri programiranju in pri uveljavitvi (uresničitvi) teh programov.

Smernice, ki so razdeljene na tri dele, v prvem obravnavajo predpogoje za boljšo konkurenčnost regij, $v$ drugem evropsko strategijo za zaposlovanje (več zaposlenih) in v zadnjem razvoj mestnih in podeželskih območij in njihov prispevek k uravnoteženemu prostorskemu razvoju. Prva dva dela opisujeta predvsem tehnične in infrastrukturne predpogoje (prometna infrastruktura, telekomunikacije, varstvo okolja, socialna vprašanja itd.).

\section{Predlog opredelitve podeželskih prostorov v R Avstriji}

Programski dokument za skupinsko iniciativo EU LEADERplus ${ }^{7}$ je pripravilo avstrijsko ministrstvo za kmetijstvo in gozdarstvo za členitev oz. opredelitev podeželskih prostorov, ki predlaga sledečo možno členitev:

- tip A: podeželje, ki leži v bližini urbanih središč, ter območje, ki leži v bližini nadregionalno in regionalno pomembnih prometnih osi;

- tip B: redko poseljeni podeželski prostor v večji oddaljenosti do urbanih središč;

- podtipi:

5 EUROPÄISCHE KOMMISSION; Die Strukturfonds und ihre Koordinierung mit dem Kohäsionsfonds, Leitlinien fŁr die Programme des Zeitraumes 2000 - 2006; Mitteilung der Kommission.

6 EUROPÄISCHE KOMMISSION; Zweiter Bericht Łber die soziale und wirtschaftliche Kohäsion (BrŁssel, 2001).

7 BUNDESMINISTERIUM FiR LAND- UND FORSTWIRTSCHAFT; LEADER+

Programmplanungsdokument für die Strukturfondsperiode 2000-2006, Version 3.3; Datum: 5.12.2000. 
B 1: podeželski prostor na kmetijsko primernih in ugodnih območjih;

B 2: podeželski prostor s pretežno turistično rabo (- turistični prostori);

B 3: redko poseljeni prostori z ekstenzivnim kmetijstvom z možnostmi za razširitev gospodarske podlage za preživetje;

B 4: redko poseljena in strukturno šibka podeželska območja, kjer so manj ugodni pogoji za kmetijstvo in so slabše dosegljiva.

\section{Aktualni programi pri podpori in pospeševanju podeželja}

Na tem mestu je predstavljen predvsem program LEADERplus, ki je namenjen pospeševanju podeželja s strukturnimi težavami. V programskem dokumentu za Avstrijo so začrtane predvsem pomembne smernice razvoja podeželja, ki imajo večje strukturne težave in imajo periferno lego. Začrtane so prioritete in programski ukrepi, ki naj bi se v Avstriji podpirali s tem programom.

LEADERplus zasleduje cilj obstoja in razvoja ter krepitve funkcijsko sposobnega življenjskega in gospodarskega podeželskega območja.

Program pa izpostavlja tudi posebne cilje:

(1) podpora regionalnim inovacijam;

(2) ohranitev in okrepitev regionalne identitete;

(3) zagotovitev dohodka prebivalstvu;

(4) vključitev programa LEADERplus območij v širšo regionalno povezavo;

(5) intenziviranje in razširitev transnacionalnega in čezmejnega sodelovanja;

(6) intenziviranje regionalnega sodelovanja na nacionalni ravni.

Tozadevno je R Avstrija pripravila tri posebne strategije, preko katerih naj se podpira:

1. območne, integrirane razvojne strategije;

2. sodelovanje med podeželskimi območji;

3. mreženje - kontaktna ustanova.

\section{Regija CARNICA Rož}

$\checkmark$ naslednjem poglavju želim predstaviti primer regionalne zveze (lahko se imenuje tudi regionalna razvojna agencija) CARNICA Rož, ki združuje devet južnokoroških občin, najbolj vzhodno leži občina Sele, najbolj zahodno pa 
občina Šentjakob v Rožu. Pred ustanovitvijo regionalne zveze leta 1995 je bila ustanovljena turistična zveza, ki je združevala in $v$ katero so bile vključene vse občine (razen občin v okraju Beljak - dežela, to sta občini Rožek in Šentjakob v Rožu). Leta 1995 je Avstrija postala polnopravna članica EU. S 1.1.1995 so potem v Avstriji začeli veljati tudi razni pospeševalni programi, ki se financirajo preko strukturnih skladov Evropske unije (EU). Kot podeželska in obmejna regija je novo ustanovljena CARNICA želela tudi participirati in črpati finančna sredstva predvsem iz sredstev skupinske iniciative LEADER II. in INTERREG II. Regija je leta 1995 kandidirala za status LEADER II. regije in bila izbrana s strani koroške deželne vlade in avstrijske vlade kot ena izmed treh koroških regij. Podlaga kandidaturi je bil izdelan program (regionalni razvojni program) z jasno definiranimi prioritetami in ukrepi. Glavna tri področja delovanja med leti 1995-1999 so bila: turizem, kmetijstvo in gozdarstvo ter gospodarstvo.

\section{Turizem}

Regija ni intenzivna turistična regija, leži pa na robu intenzivnih turističnih regij v bližini večjih koroških jezer. Prednost regije je bližina prepoznavnih turističnih središč in izvirna ter nepokvarjena narava.

\section{Kmetijstvo in gozdarstvo}

Poleg tradicionalnega kmetijstva ima $v$ regiji velik pomen tudi gozdarstvo. Splošen problem kmetijstva $v$ regiji je majhna struktura posestev (razdrobljenost kmetijskih zemljišč) in s tem povezan majhen delež polnih kmetov. S tem, da so kmetje primorani poleg dela na domači kmetiji poiskati tudi zaposlitev $v$ kakšnem podjetju, kmetijstvo pogostokrat postane zgolj "konjiček". V 90ih letih (posebno po letu 1995) je postal močan in prevladujoč tudi trend direktnega trženja kmetijskih proizvodov. Tudi v CARNI$\mathrm{Cl}$ smo temu trendu ustregli in s pomočjo naših kmetov vpeljali nekaj projektov. Pomemben projekt je tudi gozdno gospodarska skupnost, ki ima več kot 400 članov in letno okol 30. mio. ATS prometa.

\section{Gospodarstvo}

Gospodarsko gledano je regija s približno 26.000 prebivalci relativno šibka. Edini močnejši gospodarski center je občina oz. mesto Borovlje (Ferlach). To mesto ima dolgo tradicijo $v$ železarski industriji in $v$ puškarstvu. Kljub temu se je v zadnjih letih opazilo, da so Borovlje in celotna regija (devet občin) enostavno premajhne za izvajanje večjih in velikih gospodarskih projektov. 


\section{Konkretni projekti na področju turizma}

CARNICA je na področju turizma izbrala predvsem ponudbo za kolesarjenje in pohodništvo. Poleg izgraditve in posodobitve kolesarskih poti ob Dravi so $v$ zadnjih letih bile pripravljene tudi razne tematske poti. Dodatna in izredno zanimiva zamisel je tudi povezava (simbioza) med kulturo (umetnostjo) in krajino. Regija oz. odgovorni v regiji se zavedajo, da so samo urejene kolesarske poti in lepa narava premalo za turistični razvoj, potrebno je najti tudi alternativno in drugo pozicijo, ki potem privabi turiste. Tozadevno se želi CARNICA uveljaviti z raznimi LANDART projekti, ki naj prinesejo zgoraj omenjene rezultate. Poleg LANDART projektov (umetnost v prostoru) je še dovolj takih, ki so se odvijali na raznih drugih področjih. Na tem mestu je treba izpostaviti sodelovanje posestnikov gradov. Ti gradovi so v zadnjih letih postali gotovo centri kulturnega in umetniškega življenja in privabljajo lepo število turistov.

\section{Smernice regije za obdobje 2000 - 2006}

Kot v programskem obdobju med leti 1995-1999 je regionalna zveza oz. regionalna razvojna agencija tudi za zdaj veljavno programsko periodo pripravila svoje smernice. Odgovorni so se odločili, da želijo kandidirati za status LEADERplus regije (skupinska iniciativa, ki podpira razvoj podeželja). V smernice regije smo zapisali najpomembnejše točke in ukrepe, ki so potrebni za pozitiven razvoj. Težišča so podobna kot v prejšnji periodi, npr. turizem, kmetijstvo in gozdarstvo, kultura, gospodarstvo.

\section{Pogled v prihodnost - kandidatura za status LEADERplus}

Avstrijsko ministrstvo za kmetijstvo, gozdarstvo in okolje je pripravilo programski dokument za skupinsko iniciativo/ pobudo LEADERplus, ki podpira podeželje, še posebej pa strukturno šibka območja. Program je Evropska komisija sklenila in ga predložila državam kandidatkam. Do konca maja 2001 so v Avstriji morale regije vložiti svojo kandidaturo za projekte. Kandidirati je bilo možno pod različnimi naslovi (strategijami).

Regionalna zveza CARNICA se je odločila, da kandidira pod naslovom Izboljšanje življenjske kvalitete (podnaslov kandidature: valorizacija narave in kulture). 
V pripravi na kandidature je koroška deželna vlada regijam določila, da morajo ustanoviti LAG - Lokalne akcijske skupnosti (Lokale Aktionsgruppe), ki naj bi bile po možnosti večje (po velikosti in številu prebivalcev) od LEADER II. regij. Tozadevno se je CARNICA odločila, da ustanovi skupaj z dvema drugima regionalnima zvezama LAG Spodnja Koroška. Ta LAG se je potem tudi ustanovila in tako ustregla predpisom in zahtevam s strani deželne vlade. Na podlagi dosedanjega dela in izkušenj ter projektnih ciljev in predstav za naprej se je potem pripravil regionalni razvojni načrt s prioritetnimi ukrepi, ki naj bi se $v$ naslednjih šestih letih uvedli in izvajali na našem območju s podporo iniciative LEADERplus.

\section{Čezmejno sodelovanje}

Kot obmejna regija je CARNICA že ves čas od ustanovitve naprej izvajala projekte in sodelovala z regijami v Sloveniji. Posebne partnerske odnose ima regija z regionalnimi razvojnimi agencijami na Gorenjskem. V novem programskemi obdobju je Avstrija pri dodeljevanju finančnih sredstev dobila razmeroma veliko sredstev za skupinsko iniciativo INTERREG. Po pripravi skupnega programskega dokumenta je s strani koroške deželne vlade CARNICA bila poverjena kot regionalno koordinacijsko mesto za izvajanje tega programa. Izvedli so se tudi že razni projekti. Vsi projekti so povečini potekali na turističnem področju. Projekti so imeli dejansko čezmejno povezavo - že v začetni fazi so se pripravljali in potem tudi izvajali skupno. Taki in podobni projekti imajo veliko pozitivnih faktorjev (spoznavanje in komunikacija med raznimi akterji na obeh straneh meje).

V prihodnje je cilj CARNICA regije prav gotovo ta, da se stiki še intenzivirajo in resnično privedejo do tega, da se bo naša regija smatrala kot skupna regija in da bo čezmejno sodelovanje pridobilo pozitiven prizvok in bo temeljilo na medsebojnemu spoštovanju in iskanju najboljših rešitev za skupen razvoj.

\section{Prikaz projektov v regiji - primer občine Sele}

\section{Gradnja gospodarskega centra v Selah}

Po pristopu Avstrije k EU leta 1995 so se selski kmetje odločili, da postavijo skupen gospodarski center. Projekt je bil podprt tudi s strani programa 
cilj 5B. Sele so značilna gorska vas na višini 950 m, v kateri prevladuje kmetijstvo (živinoreja) in gozdarstvo. Zaradi strogih higienskih predpisov je kmetom bilo onemogočeno, da bi klali svojo živino doma. Odločitev za skupinsko gradnjo klavnice in predelovalnice se je izkazala kot zelo pomembna in pravilna. Namesto, da bi vsak posamezen kmet šel v lastno (veliko višjo) investicijo, so se odločili za skupno. Kmetje so razvili (vsak zase) tudi svojo prodajno mrežo. Razlika na glavo živine je okoli 30 \% če jo prodaš mesarju ali če živino zakolješ sam. Cilj selskih kmetov je tudi, da v nekaj letih razvijejo skupno blagovno znamko.

\section{INTERREG projekt Prostor umetnosti}

Konec leta 2000 so se v Selah začeli pogovori o skupnem čezmejnem projektu z občinama Tržič in Škofja Loka. Projekt je dobil ime Prostor umetnosti. Cilj projekta v prvi fazi je, da se intenzivno sodelovanje med občinami na raznih področjih, med drugim na področju kulture, intenzivira. $V$ nadaljevanju je cilj projekta prispevati $k$ pospeševanju gospodarstva in $k$ dvigu regionalne zavesti, ki je izrednega pomena. Projekt je namenoma zastavljen tako, da se iz njega lahko razvije dovolj spremljajočih dejavnosti in tako pride do mnogostranskih skupnih učinkov.

\section{Zaključek}

1. Podeželje (še posebej območje med Slovenijo in Koroško) ima veliko razvojnih možnosti, predvsem na področju razvoja turizma, modernih tehnologij in ohranitve sonaravnega oz. naravi primernega kmetijstva in gozdarstva. Od nas samih bo odvisno, v kolikšni meri nam bo uspelo ohraniti in razvijati ta naravni potencial.

2. Klasično delitev na centralna in periferna podeželska območja je potrebno nadomestiti z novo terminologijo. Obstaja namreč "samostojno" in “odvisno" podeželje, ki pa se razlikujeta predvsem v tem, da prebivalci na samostojnem podeželju razvoj poskušajo z danimi možnostmi oblikovati sami, odvisni prostori pa se pogosto prepuščajo in podajajo $v$ odvisnost od centrov.

3. Čezmejno sodelovanje je izrednega pomena. Da je uspešno na obeh strani meje, je potrebna najprej pripravljenost za sprejetje soseda. 
Pomembno je namreč, da se čezmejno sodelovanje ne izkorišča z ene strani in se tako ne ustvari neenakopravni položaj. Izbrati je potrebno take skupne točke razvoja, ki koristijo obema stranema in pripomorejo k boljšemu razvoju celotnega območja. 


\section{CROSSBORDER CO-OPERATION BETWEEN CARINTHIAN AND SLOVENIAN RURAL AREA}

\section{Summary}

The countryside was subject to great changes, which were so great in the second half of the 20th century as never before. As the development of regions was not equal everywhere, it was required to reorganise the development by the national assistance. In the beginning of 70s the Austrian conference of physical planning was established with the purpose to prepare for and advise the federal government and regional governments. At first they formed various supporting and promoting programmes to assist the agriculture and forestry. The countryside development in collaboration with local factors was indispensable. They first organised programmes to support economically weak regions.

In 1999 the EU adopted a concept of European development perspectives (European Spatial Development Perspectives - ESDP), which contained directives for the development of physical planning and spatial development.

After the accession to the EU, the Austrian regions were ready to stand as candidates also for the EU funds. In 1995 the regional union (regional development agency) CARNICA was established, and it unites nine southern Carinthia communities. By means of the EU programmes (mainly group initiatives LEADER II. and INTERREG II.) some projects in the field of tourism, agriculture, and forestry were carried out. In the following years a great attention will mainly be paid to the cross-border co-operation with Slovenia. 


\section{Viri in literatura}

Arbeitsgrundlage der Kommissionsdienststellen, 2000.

Die Gemeinschaftsinitiativen 2000-2006. Europäische Kommission.

CBC Programi Slovenija - Avstrija, 2001. Agencija RS za regionalni razvoj, Regionalna pisarna Kranj, $15 \mathrm{~s}$.

Das EUREK - Europäisches Raumentwicklungskonzept, 1999. Europšische Kommission. $87 \mathrm{~s}$.

INTERREG III. A ÖSTERREICH - SLOWENIEN, 2000. Programmplanungsdokument für den Zeitraum von 2000-2006. Expert Draft, $169 \mathrm{~s}$.

INTERREG in Österreich, 1999. Bundeskanzleramt (BKA). Wien, $56 \mathrm{~s}$. MARTINOS, H., 1992. INTERREG Grundlagendokument LRDP, LACE Consultant.

Neunter Raumordnungsbericht, 1999. Österreichische Raumordnungskonferenz (ÖROK). Wien, 319 s.

PHARE - Erfolgreich Arbeiten mit PHARE, 1999. Europäische Kommission. 67 s.

Preliminarni državni razvojni program za pristop 2000-2002, 2000. Ministrstvo za ekonomske odnose in razvoj (MEOR). Ljubljana, $129 \mathrm{~s}$.

Regelmässiger Bericht 2000 der Kommission Über die Forstschritte Sloweniens auf dem Weg zum Beitritt, 2000. Europäische Kommission, $113 \mathrm{~s}$.

ROBLEK, I., 2000. Chancen für Südkärnten im Hinblick auf grenzüberschreitende Regionalentwicklung nach einem EU Beitritt Sloweniens. Diplomarbeit am Institut für Geographie und Regionalforschung der Universität Klagenfurt, 271 s.

Strategija regionalnega razvoja Slovenije, 2001. Agencija RS za regionalni razvoj (prvi osnutek). Ljubljana, $30 \mathrm{~s}$.

White Paper on Regional Development Strategy, 1998. Ministrstvo za ekonomske odnose in razvoj (MEOR). Ljubljana, $47 \mathrm{~s}$.

http://www.gov.si; Denarna pomoč za pripravo članstva, citirano maja 2001. 